\title{
Articles
}

\section{How Do Japanese Junior High School English Teachers React to the Teaching English in English Policy?}

\section{Tomohisa Machida Akita International University}

The Japanese Ministry of Education (MEXT) proposed the teaching English in English (TEE) policy in junior high schools (JHSs) in 2013. According to the new Course of Study (MEXT, 2017), JHS English teachers will be required to teach English in English starting in 2021. A study of JHS English teachers' reactions to the new policy is reported in this paper. Participants included 98 public JHS English teachers (31 males and 67 females) in the northeast region of Japan. Teachers' responses to the policy were investigated using the Teacher Foreign Language Anxiety Scale (TFLAS; Horwitz, 2013), a background questionnaire, class observations, and individual interviews. Due to JHS teachers' lack of confidence in using English for instruction and concern over students' possible struggles in learning, teachers were anxious about TEE. In addition, many teachers wanted practical training opportunities to develop their English communication skills to be ready for successful policy implementation.

文部科学省は2013年に、中学校でも英語の授業を英語で行う方針 (TEE: Teaching English in English)を打ち出した。そして、2017年に改訂された新しい中学校学習指導要領では、2021年 からの英語による指導が義務付けられた。本研究は、英語の授業を英語で行う方針に対する中 学校英語教師の反応を調査したものである。東北地方の公立中学校英語教師 98 名 (男性 31 名、 女性67名)が本研究に参加した。調査にあたっては、教師外国語不安スケール (Horwitz, 2013)、 質問紙、授業観察、インタビューの手法を活用した。その結果、中学校英語教師は英語を使った 指導に対する自信のなさや、生徒の英語学習が困難になるかもしれないという思いから、英語

JALT Journal, Vol. 41, No. 1, May 2019 
による指導に不安を感じていることが分かった。さらに、多くの教師はTEEが滞りなく実施される ためにも、教師自身の英語によるコミュニケーション能力を伸ばす実践的な研修の機会の充実 を望んでいた。

Keywords: English education policy; junior high school teachers; foreign language anxiety; teaching English in English

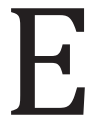

nglish education in Japan has been further advanced toward English for communication since the Japanese Ministry of Education, Culture, Sports, Science and Technology (MEXT) published the Course of Study in 2008. This national educational guideline has been published approximately once every 10 years, and it is almost always controversial in terms of the feasibility of goal attainment (Kikuchi \& Browne, 2009). The 2008 Course of Study announced the implementation of English education at the elementary school (ES) level and teaching English in English (TEE) at the senior high school (SHS) level. Soon after the 2008 publication, MEXT (2013) proposed the further development of English education at every school level by releasing its English education reform plan, declaring that "classes will be conducted in English in principle" (p. 1) in junior high schools (JHSs) to develop students' English communicative competence. The government promotes the sequential development of students' English by using English as a medium of instruction at JHSs and SHSs. In 2017, MEXT published a new Course of Study to activate the TEE policy in JHSs in 2021.

MEXT (2016) determined how many JHS English teachers currently teach English in English (see Table 1). The data show that over half of JHS English teachers use English for more than half of their utterances during lessons. However, in terms of TEE, the current results suggest that implementation of the policy in JHSs will be difficult because only approximately $10 \%$ of teachers teach English in English. Given that official enactment of the TEE policy in JHSs will occur in fewer than two years, the aim of this study was to examine the extent to which teachers are likely to implement the policy and investigate potential obstacles by exploring JHS teachers' reactions to the new policy. Surveys, interviews, and observations of English lessons were used to understand JHS teachers' pedagogical and affective concerns over the governmental educational reform. 
Table 1. JHS Teachers' Use of English

\begin{tabular}{lccc}
\hline English Use & $\begin{array}{c}\text { 7th-grade } \\
\text { teachers }\end{array}$ & $\begin{array}{c}\text { 8th-grade } \\
\text { teachers }\end{array}$ & $\begin{array}{c}\text { 9th-grade } \\
\text { teachers }\end{array}$ \\
\hline More than 75\% & $10.3 \%$ & $9.1 \%$ & $9.4 \%$ \\
$50 \%-75 \%$ & $48.0 \%$ & $47.8 \%$ & $45.4 \%$ \\
Less than 50\% & $41.7 \%$ & $43.1 \%$ & $45.2 \%$ \\
\hline
\end{tabular}

\section{Obstacles to the Implementation of the TEE Policy}

Although MEXT officially initiated the TEE policy in SHSs in 2013, the implementation of the policy was more challenging than expected. MEXT (2016) reported that only $13.7 \%$ of SHS English teachers used English for more than $75 \%$ of their utterances during lessons for the subject English Communication I. Three years after the official implementation of the TEE policy in SHSs, MEXT revealed that the policy had not been successfully carried out.

One of the reasons for the low implementation rate is the pressure teachers face when dealing with grammar-based high-stakes tests (Kikuchi \& Browne, 2009). Grammar-focused juken eigo [English for entrance exams] and yakudoku (an adaptation of the grammar-translation method) in the L1 have been widely adopted in SHSs as washback of university entrance examinations, although "most university exams don't actually require students to translate" (Gorsuch, 1998, p. 27). To reform the grammar-based approach, "a more communicative-oriented approach in ... teaching and testing" (Sakamoto, 2012, pp. 414-415) has been advocated. Thus, the Japan Association of National Universities (2017) announced a reform of the Center Test, the grammar-based high-stakes test for university entrance examination, by integrating all four English language skills (listening, reading, speaking, and writing). The Center Test will be taken over by private-sector tests, such as TOEFL, and the new test will be introduced in 2020. Due to the change of the test format, teachers' increased use of English for instruction might be expected for communicative purposes.

Another reason for the low implementation rate is SHS teachers' lack of confidence in speaking English for communication. In Nishino's (2011) study, SHS English teachers assessed their own speaking ability as weaker than their listening, reading, and writing abilities. Their lack of communicative English learning experience also impeded their use of English in a communicative way. Glasgow (2013) found that SHS teachers who did not have 
confidence in their English pronunciation tended to be the most anxious about engaging in English medium instruction.

Many researchers (e.g., Horwitz, 2013) have found that nonnative teachers frequently mentioned foreign language anxiety. MacIntyre (1999) defined this as "the worry and negative emotional reaction aroused when learning or using a second language" (p. 27). According to Suzuki and Roger (2014), foreign language anxiety among Japanese SHS teachers prevented them from using English during lessons. They reported that 13 out of 15 SHS English teachers experienced some degree of foreign language anxiety when they used English in class, and most teachers conducted lessons mainly in Japanese due to their negative reaction toward English. The researchers identified two major causes for teachers' anxiety. The first cause was "teacher cognition about their role in relation to target language use" (p. 185), which means teachers' lack of confidence in their use of English. Teachers were afraid of making mistakes in front of students, because they thought it would lead to the deterioration of their authority as an English teacher. The other cause was "teacher cognition about learners" (p. 188); they had concerns about students left behind and returnees as well as the relationship between communicative lessons and grammar-based highstakes tests. SHS English teachers thought that using Japanese would help students understand English lessons better and prepare them to take university entrance examinations.

As with SHS teachers, Japanese ES teachers also experience foreign language anxiety (Machida, 2016). Since the official implementation of Foreign Language Activities (English language education) in fifth and sixth grades in 2011, ES teachers have been required to team teach with native Englishspeaking assistant language teachers (ALTs). Machida and Walsh (2015) pointed out that foreign language anxiety affected ES teachers' successful collaboration with native English-speaking ALTs. The reasons for their anxiety in using English stem from a lack of confidence in English communication and a lack of experience in preparing English lessons (Machida, 2016).

Foreign language anxiety weakens nonnative English-speaking teachers' confidence about the target language, especially when they compare their English proficiency with that of native speakers. Their language proficiency often becomes a cause of stress among nonnative teachers (Mousavi, 2007). Nonnative English-speaking teachers tend to pursue "an idealized level of proficiency" (Horwitz, 1996, p. 367), such as a native speaker's level, and the proficiency gap between them triggers anxiety among nonnative Englishspeaking teachers. In a similar vein, Nishino and Watanabe (2008) argued 
that "many Japanese English teachers perceive their speaking skills as weak and believe that their authority might be tarnished if they make mistakes in front of students" (p. 134).

In other Asian countries, TEE has been implemented at every school level, and it has affected teachers in terms of their confidence in the use of English. For example, with reference to to the TEE policy that began in Korea in 2001 (Choi, 2015), Kim and Kim (2004) investigated Korean EFL teachers' foreign language anxiety and its causes. They reported that Korean teachers strongly believe that English teachers should have a comprehensive understanding of the English language, but many were concerned about TEE. Their limited English proficiency, lack of confidence in speaking English, and lack of preparation for TEE were reported as the main causes of their anxiety. Kim and Kim warned that the TEE policy threatened the teachers' authority as English teachers.

Researchers who are against English-only policies have pointed out benefits of L1 use in L2 classrooms (e.g., Meyer, 2008; Nation, 2003; Storch \& Wigglesworth, 2003; Weschler, 1997). The use of the students' native language helped students fully understand the meaning of focused tasks (Nation, 2003), complete the tasks "at a higher cognitive level" (Storch \& Wigglesworth, 2003, p. 767), and reduce their language anxiety (Meyer, 2008). The L1 was also useful for teachers to conduct classroom management and comprehension checks (Meyer, 2008). However, in EFL contexts, "too much use of the native language in the classroom" (Brown, 2007, p. 247) has often received attention for being problematic. Japanese English teachers "overwhelmingly use Japanese" (Gorsuch, 1998, p. 10) as a means of instruction in class due to their "adhere[nce] to the traditional grammar-translation method" (Nishino \& Watanabe, 2008, p. 134). MEXT (2016) found that more than $51 \%$ of SHS teachers and $41 \%$ of JHS teachers mainly used Japanese for teaching the subjects Communication English I and English respectively, and they used this to argue that teachers provided insufficient target language input to students. Many researchers, even if they believe in the benefits of the L1, agree on the importance of L2 input for the development of students' proficiency in the target language (e.g., Ford, 2009; Nation, 2003). In addition, English language instruction has been adopted as a global trend. Dearden (2015) reported that $70.9 \%$ of public secondary schools in 55 countries, including Japan, have officially accepted the idea of English as a medium of instruction not just for English and literature, but also for other subjects, such as math and science. Recently in Japan, MEXT-designated Super English Language High Schools started to develop English education through TEE (Nishino \& Watanabe, 2008; Yoshida, 2003). 
Given the increasing importance being placed on TEE, further pressure on teachers to do so can be anticipated. However, that appears incongruent with the evidence that language anxiety may prevent such a policy's effective implementation. Therefore, this study sought to assess Japanese JHS teachers reactions to the TEE policy as a way to contribute to advancing the discussion around it.

\section{Method}

\section{Participants}

Ninety-eight public JHS English teachers (67 females and 31 males) in a northeastern prefecture (approximately 33.7\% of full-time JHS English teachers in the prefecture) participated in this study. All were nonnative English speakers. They taught English weekly to seventh- through ninthgrade students. The teachers' average length of teaching experience was 19.1 years. The participants responded to an anxiety scale and a background questionnaire. Among the participants, 13 teachers (nine female and four male) from five schools additionally agreed to take part in individual semistructured interviews at their home schools and let the researcher observe their lessons. The length of the teaching experience of these 13 teachers ranged between 2 and 28 years ( $M=16.2$ years).

\section{Instruments}

\section{Teacher Foreign Language Anxiety Scale (TFLAS)}

Horwitz (2013) developed the TFLAS to evaluate a teacher's anxiety level about his or her foreign language proficiency. The 18-item survey is scored on a 5-point Likert scale ranging from 1 (strongly disagree) to 5 (strongly agree). The TFLAS includes both regular and reverse-scored items. To determine the anxiety level, all responses are summed up, and the total score is divided by 18. According to Horwitz, an average of around 3 on the TFLAS suggests the teacher may have a slight anxiety about their language proficiency. As with other studies (e.g., Tum, 2012), teachers whose average scores are 3 or higher were considered anxious teachers in this study. Although the TFLAS was originally created in English, the researcher translated the scale into Japanese and used the Japanese version in this study. 


\section{Background questionnaire}

The background questionnaire was administered to participants to elicit each teacher's (a) gender, (b) years of English teaching experience at JHS, (c) formal in-service training experience related to teaching methods, (d) formal test-taking experience (e.g., TOEFL, TOEIC, or EIKEN) and their highest scores, and (e) self-assessed English proficiency level. The results were utilized to understand JHS English teachers' demographic data and analyze sources of their anxiety. In addition, the questionnaire included an open-ended question about MEXT's new TEE policy. JHS English teachers were asked to describe their opinions and feelings about TEE. The collected data were analyzed to identify pedagogical gaps between teachers' current instructional methods and the English-mediated instruction in an effort to reveal obstacles to the implementation of the new policy.

\section{Class observations and interviews}

Additional explorations were conducted at willing teachers' schools individually a few months after collecting written data. After obtaining permission from each school principal for class observations and interviews, the researcher made a single visit to each of the five schools where the 13 teachers worked, observed 50-minute lessons (one 50-minute lesson for nine teachers and two 50-minute lessons for four teachers because of each school's schedule), and conducted interviews of approximately 30-minutes with each of the 13 teachers. The aim of the class observations was to examine how and to what extent each JHS teacher used English for instruction in class. Because the class lessons could not be recorded on video, the researcher took careful field notes during observations. In addition, interviews explored teachers' feelings and struggles about TEE. Individual interviews took place in a secured private room in each school and were recorded for transcription after obtaining each participant's permission.

\section{Procedure}

To collect data, the TFLAS and questionnaire were administered to teachers during prefectural in-service training at three different locations in the prefecture. The prefectural board of education administers all public schools by dividing them into three different regions (North, Central, and South). Each region has a local education office that disseminates governmental policies to each teacher by providing in-service teacher training. These three regional local offices annually offer one-day in-service teacher 
training sessions to JHS English teachers. During one such training session, the TFLAS and background questionnaire were distributed to participants, and JHS teachers were given enough time to complete the written forms. After the quantitative data collection, the researcher contacted the prefectural board of education to ask for permission to conduct interviews and class observations in each region. Once the researcher received the local government's permission for class observations and interviews, the three regional local education offices provided each school's information about English teachers to the researcher. After obtaining permission from each school principal, the researcher and the English teachers in each JHS then arranged possible visiting dates for class observations and interviews. Prior to interviewing teachers individually, the researcher observed their English lessons in classrooms.

\section{Data Analysis}

All participants completed the TFLAS and background questionnaire. Once the TFLAS data were collected from each teacher, their responses on the 5-point Likert scale (i.e., ranging from strongly agree to strongly disagree) were converted to specific points between 1 and 5 . The mean score was computed and utilized to analyze each teacher's anxiety level: the higher the number, the higher the level of anxiety. Their responses to the background questionnaire were categorized into each item and used to understand teachers' English proficiency level and opinions of the TEE policy.

All the interview data were transcribed and analyzed to understand how teachers felt about TEE. Field notes for class observations, which included information about what activities teachers used and how they instructed, were also analyzed to identify teachers' techniques and strategies for TEE during lessons.

\section{Results}

\section{JHS Teachers' Anxiety About English}

Unlike ES teachers, who showed a high level of anxiety (Machida, 2016), JHS English teachers showed a relatively low level of anxiety $(M=3.05, S D$ $=0.44$ ), although their average language proficiency anxiety level was still considered "slightly anxious" (Horwitz, 2013, p. 266). Cronbach's alpha (.82) suggests that the anxiety scores were reliable in this study. Table 2 shows the distribution of JHS teachers' anxiety levels: low, medium, and high. As 
noted above, teachers in the medium- to high-anxiety groups were considered anxious teachers in this study, indicating that 44 teachers (44.9\%) felt anxious about their English proficiency.

Table 2. Teacher Anxiety Levels

\begin{tabular}{lcccl}
\hline Anxiety group & $N$ & Possible range & $M$ & $S D$ \\
\hline High anxiety & $1(1.0 \%)$ & 4.06 & 4.06 & 0 \\
Medium anxiety & $43(43.9 \%)$ & $3.00-3.78$ & 3.35 & 0.23 \\
Low anxiety & $54(55.1 \%)$ & $1.78-2.94$ & 2.65 & 0.29 \\
\hline
\end{tabular}

\section{JHS Teachers' Backgrounds}

Results from the background questionnaire provided information about participants' experience with in-service training about English teaching methods, formal tests (TOEFL, TOEIC, or EIKEN), and self-assessments of their English proficiency level.

Regarding teachers' in-service training experience, 86 teachers (87.8\%) had taken at least one TESOL methodology course through their local government training. Although their years of teaching experience ranged between 2 and 31 years, the prefecture's in-service training system systematically supported each teacher's instructional development at all career stages. For example, the prefecture provides skill-development courses for teachers at specific career stages, such as in the third year and the fifth year, as well as annual English training courses for any teachers who want to improve their lessons. In addition to the TESOL methodology course, teachers can take other skill-based courses, such as listening and speaking, as well as courses for classroom activities that are offered by the prefectural board of education. JHS teachers can also learn how to teach English to ES students. In this prefecture, the board of education sometimes transfers teachers between ESs and JHSs for educational and administrative reasons.

Regarding their test-taking experience, 29 teachers (30.0\%) took at least one formal test after starting their teaching career. Because the formal test scores are valid for a limited time (e.g., two years for TOEFL), teachers reported their highest scores within their recent test-taking experience. Although MEXT (2013) requires JHS English teachers to prove their English proficiency by scoring over 80 points on TOEFL iBT, 730 points on TOEIC, or passing Grade Pre-1 on EIKEN, only 20 teachers (20.4\%) satisfied the requirements. 
In addition, most JHS English teachers evaluated their own English proficiency level as intermediate (Table 3). Teachers were asked to assess what they could do in English from five alternatives: (a) greet someone, (b) shop and order food, (c) have a general conversation, (d) understand an academic lecture, or (e) discuss a specific topic. This question was translated into Japanese and used as a part of the background questionnaire. JHS teachers chose the most difficult feasible task among the alternatives.

Table 3. Teachers' Self-Reported English Proficiency Level

\begin{tabular}{lrr}
\hline Proficiency level & $N$ & $\%$ \\
\hline (a) greet someone & 5 & 5.1 \\
(b) shop and order food & 41 & 41.8 \\
(c) have a general conversation & 36 & 36.7 \\
(d) understand an academic lecture & 10 & 10.2 \\
(e) discuss a specific topic & 5 & 5.1 \\
\hline
\end{tabular}

Almost $80 \%$ of the teachers fell into two categories: (b) shop and order food and (c) have a general conversation. Despite MEXT's expectation toward JHS English teachers' high English proficiency, the results indicated that teachers' current levels of English proficiency did not successfully meet MEXT's requirements. For example, a score of 80 points on TOEFL iBT, one of MEXT's requirements for JHS English teachers, is also the minimum passing score for international applicants to apply for many American universities. Thus, people scoring 80 points on the test are thought to have basic academic English skills to study by (d) understanding an academic lecture and (e) discussing a specific topic. However, only $15.3 \%$ of the teachers in this study evaluated themselves as able to perform these communication tasks, indicating that most teachers might not have strong confidence in their own communicative competence in English.

\section{JHS Teachers' Reactions to the TEE Policy}

Teachers' responses to the question about the TEE policy were categorized into four main opinion categories: (a) anxiety about the teacher's own command of English, (b) concerns about students' learning, (c) disagreement with the new policy, and (d) joy of transformation to communicative lessons (Table 4). Because their answers were written in an open-ended style, some answers 
fell into more than one of the four main opinion categories. More than half of the teachers mentioned anxiety about their command of English. This included three kinds of anxiety: anxiety about their own English proficiency, anxiety about using appropriate expressions with students with different proficiency levels, and anxiety about explaining grammar in English.

Table 4. Teachers' Opinions Toward the TEE Policy

\begin{tabular}{lrr}
\hline Opinion categories & \multicolumn{1}{c}{$n$} & \multicolumn{1}{c}{$\%$} \\
\hline (a) anxiety about the teacher's own command of English & 51 & 52.0 \\
(b) concerns about students' learning & 42 & 42.9 \\
(c) disagreement with the new policy & 9 & 9.2 \\
(d) joy of transformation to communication lessons & 8 & 8.2 \\
\hline
\end{tabular}

\section{Anxiety about the teacher's own command of English}

Several teachers replied that their English abilities were not sufficient to teach English in English. One teacher commented, "I am not confident about my English-speaking ability. Unfortunately, I have not reached a high enough level to give students English-mediated instruction." Another responded, "I need to develop my English proficiency." In addition, JHS teachers were diffident about their own English ability to use appropriate expressions with groups of students with mixed proficiency levels. Unlike SHS teachers teaching rather uniform proficiency levels of students within each school, JHS teachers have students with a wide variety of proficiency levels, from low proficiency to an advanced level, in one classroom. According to one teacher, "it would be difficult to manipulate my English for effective explanation depending on students' levels of English ability." In addition, spontaneously switching to "simple" English or providing "alternative expressions" would make it difficult for teachers and make them feel uneasy when students appeared not to understand the teachers. Furthermore, because grammar-translation instruction-yakudoku-was still emphasized in secondary schools, introducing grammatical form and meaning seemed to be an indispensable aspect in English lessons. Thus, one teacher responded, "with my English, I am anxious whether or not I can make students understand complicated grammar rules by using only English." TEE implies a communicative, student-centered approach that focuses on fluency, whereas grammar-translation stands in direct opposition to all of these things: It is a noncommunicative, teacher-centered 
approach that focuses on accuracy. The contradiction between the two concepts also provoked anxiety among teachers.

\section{Concerns about students' learning}

Approximately $43 \%$ of the teachers expressed their concerns over students' learning. They worried that students would lose their motivation to study English when teachers shifted to TEE. One teacher commented, "I am afraid that the number of students who give up listening to English might increase because they cannot understand English instruction." Some JHS teachers also thought that TEE would ultimately demotivate students to study English as the teachers assumed that students could not comprehend English sentences or words without translating them into their native language, Japanese. One teacher stated, "because students are Japanese, they must understand grammar rules better in Japanese." Although Suzuki and Roger (2014) argued that an exam-related factor was one of the major concerns among SHS teachers, this was not the case for JHS teachers. Of course, JHS teachers also pointed out a contradiction between communication-based instruction and current grammar-based entrance examinations. However, they anticipated that high school entrance examinations would be reformed along with this TEE policy. One teacher commented, "I want to know the future direction of entrance examinations. I hope the high-stakes tests will be conducted with various elements including a speaking test." Thus, JHS teachers were more concerned about students' progress in learning English than test styles on high school entrance examinations.

\section{Disagreement with the new policy}

Less than $10 \%$ of the teachers disagreed with the new policy due to their busyness and doubt about its effectiveness. Teachers are not involved in top-down policy development (Machida \& Walsh, 2015) and they know that they have no option but to follow it. As such, it seems healthy to have teachers who complained about their working conditions and the feasibility of MEXT's goal attainment involved in this process. Some teachers explained their busy lives in school, mentioning administrating homeroom and operating school division duties in addition to teaching English classes. In fact, Bannai, Ukawa, and Tamakoshi (2015) reported that Japanese JHS teachers worked the most hours per week (53.9 hours) among OECD countries. Overworked teachers seemed reluctant to accept the policy reform, with one stating "I do not have enough vigor or time to adopt the new policy." Others questioned the effectiveness of TEE. One teacher commented, "it is 
impossible to develop all Japanese people's English proficiency to a practical level through applying the new policy." Such skeptical teachers might have thought that English was just one of nine school subjects and that weekly 4-hour English lessons would not make a difference.

\section{Joy of transformation to communication lessons}

Among the 98 participants, eight teachers (8.2\%) expressed very positive attitudes toward TEE. Although this number was very small, they believed that the new policy would lead to the transformation to more communicative lessons. They all supported the policy change and thought that TEE would be "effective and possible even in JHSs."

\section{Class Observations and Interviews}

Class observations revealed that several teachers started to teach English in English before the official implementation of the TEE policy. A total of 850 minutes of observation in JHSs were carried out for this study. Approximately half of the 13 teachers taught English alone; the other half worked with another teacher through team teaching. Although team teaching between a Japanese teacher of English and a native English-speaking ALT has been encouraged by MEXT, most observed team teaching lessons were conducted between two Japanese teachers of English. During the observations, all teachers used English for almost the entire lesson. One possible reason for this highly successful rate of TEE could be that only confident teachers willingly accepted the request for additional class observations and interviews. In those lessons, students seemed to be used to TEE and actively communicated with teachers. Each teacher also effectively demonstrated a set of instructional techniques for teaching lessons in English. For example, one teacher started his lesson with a conversational activity between pairs of students using the following instructions: "Make pairs and talk about what you like to do on weekends. First, window-side students. Go." Students discussed the topic with their classmates in English. This activity appeared to shift the classroom atmosphere to English mode. In another school, two experienced female teachers working together showed a discussion model to students for how to continue conversations in English and effectively gave corrective feedback, such as recasts, to students to facilitate their English utterances. For example, one commented, "Oh, you enjoyed the conversation" after a student said, "conversation enjoy." By performing learner-models of English speakers, the teachers tried to keep using English in class. 
Teachers' interview responses mirrored the opinions gathered via the open-ended question about the TEE policy. Interviewees did not show any disagreement toward the TEE policy because they actually taught English in English just before each interview. The three other major opinions-(a) anxiety about the teacher's own command of English, (b) concerns about students' learning, and (d) joy of transformation to communicative lessons-were clearly stated by teachers in the interviews. In addition, JHS teachers revealed their anticipation about the TEE policy implementation in JHS. During the interviews, some teachers mentioned the preceding TEE policy in Japanese SHSs that started in 2013 (MEXT, 2010). An experienced female teacher said, "after the policy changed in high schools, I wondered if the idea of teaching English in English would be implemented in JHSs someday. And it finally comes to us. Now we need to accept it." Her answer represented a sort of relief that teachers felt. They no longer had to worry about when the day would be.

Also some JHS teachers mentioned the joy of the transformation to communicative lessons. The teachers who made this statement showed a relatively lower level of anxiety. Because the teachers actually taught English in English, they seemed to understand the benefits of teaching English by using English communication with students. As one teacher stated, "it's better for students to understand English through listening to English. I think we, JHS English teachers, must teach English in English." These JHS teachers also welcomed MEXT's decision about the TEE policy. A chief teacher in a large school said:

I really appreciate the government proposing the policy. Although I taught English in English personally, it was difficult to change other teachers' ways of teaching. Once MEXT declared the teaching English-in-English policy, the impact was immense. We can finally step forward toward the same goal at prefectural and national levels.

Teachers who welcome the policy seem to have positive expectations about the future of JHS English language education in Japan.

However, at the same time, teachers expressed (a) anxiety about their own command of English and (b) concerns about students' learning. Although the 13 interviewees mostly taught English in English, they were not confident about whether their English was grammatically and pragmatically appropriate. The teachers thought they had to use English as a model for students; thus, they seemed to focus on the appropriateness of their English. 
A teacher with 28 years of teaching experience explained, "students try to imitate my English in class. When I see those students, I always feel I must speak English properly." Therefore, teachers made efforts to develop their English proficiency by taking English learning opportunities. Some teachers privately attended teacher training programs. Others studied for formal tests (e.g., TOEIC or EIKEN). Even during lessons or preparation for lessons, JHS teachers asked ALTs for help with regard to vocabulary and word choices in order to use appropriate English in front of students.

Teachers expressed their empathy toward students, especially those struggling with English. Unlike in SHSs, a wide variety of proficiency levels exists in JHS classrooms. Another teacher stated, "for successfully helping students, it's not easy for me to decide what level of English should be used and who target students are." Another male teacher confessed that "teaching in English might leave low-proficiency students and slow learners behind. I try not to do that, but...." Even teachers who already taught English in English appeared to have a hard time supporting students in mixed-level classes.

In addition, all interviewees requested further support from local boards of education to develop their English proficiency. Without sufficient governmental support, including funding, teachers face difficulty in being properly trained to meet the goals of the TEE policy. JHS teachers stated that they made efforts to secure their own learning time and opportunities themselves in their busy teaching lives. Attending even a half-day training seemed hard as they had to trade classes with other teachers to leave school early. Although local boards of education periodically offered a traditionally lecture-styled in-service training, teachers wanted more practical teacher training, such as English language training at overseas institutions. A teacher said, "I want to have a training opportunity in a foreign country to develop my English for a couple of months." Another teacher "want[ed] to be immersed in an Englishspeaking environment, such as an English immersion camp." Online training courses were also frequently requested among interviewees. According to an experienced teacher, "in my busy schedule, web-based training, for example using YouTube, would be very helpful because I need not cancel my regular classes." Taking even some time off for training can be very difficult for busy teachers. Another teacher wanted to take a sabbatical for training, but the education system rarely provides support for such sabbatical leave in Japan. JHS teachers wanted training opportunities because they seemed to notice that TEE policy would not succeed without developing their own English proficiency, especially their speaking skills. 


\section{Discussion}

\section{Mixed Feelings Toward the TEE Policy}

JHS English teachers had mixed feelings about TEE. Teachers were positive toward the new policy, but at the same time were not confident about actually implementing the TEE policy due to their anxiety. Their sources of anxiety were a lack of command of English and concerns about students' learning. When comparing JHS teachers' attitudes toward TEE with those of SHS teachers, the former showed relatively more flexibility in accepting the new policy. Although most SHS English teachers still conducted lessons mainly in Japanese (Suzuki \& Roger, 2014), all the JHS teachers observed during this study mostly kept using English during their lessons. In EFL contexts, such as Japan, TEE is necessary to increase the amount of target language input to students. It is not enough for teachers to just switch their instructional language from Japanese to English for effective lessons; they must make their English teaching more communicative to expose students to the target language effectively. JHS teachers understood the need for the pedagogical change and believed that the new policy would promote English education in Japan to the next phase. Teachers seemed to know from experience that students could learn English better through communication. Levin (2003) reported that students understood the importance of using the target language (TL) for its acquisition. He also noted that teachers with more frequent use of the target language "perceive lower levels of TL-use anxiety in their students" (p. 355).

However, JHS English teachers were not fully ready to carry out TEE due to a lack of their own English-speaking confidence and concerns about students' learning. In fact, $44.9 \%$ of the teachers were anxious about their own English language proficiency, $52 \%$ of the teachers were concerned about their own command of English, and almost $80 \%$ of the teachers did not reach the English proficiency level that MEXT required of JHS English teachers. Developing JHS teachers' English proficiency levels must be a priority to make lessons more communicative in English. Without a certain level of English proficiency (e.g., CEFR B2 or C1, Pinter, 2017), JHS English teachers do not have sufficient confidence in using English for communicative lessons. Changes do not happen overnight, but all JHS English teachers need to develop their own target language proficiency for the successful implementation of the new policy.

Regarding concerns about students, even teachers who taught English in English sometimes worried whether their lessons were effectively helping students learn English. Some teachers in this study mentioned the students' 
possible negative reaction toward TEE, but it could be that they were overly worried. Levin (2003) pointed out that "instructors may perceive higher anxiety about TL use in students than students themselves report feeling" (p. 351), and evidence from elsewhere in Asia also suggests that students may be more ready to adopt the target language as the medium of instruction than teachers (Choi \& Leung, 2017). In addition, nonnative English teachers were sensitive to their students' needs and showed empathy toward students (Reves \& Medgyes, 1994; Samimy \& Brutt-Griffler, 1999). As nonverbal cues are commonly used in exchanging messages in Japanese classrooms (Machida \& Walsh, 2015), teachers could notice even subtle cues from students needing help. JHS English teachers dedicated themselves to enhancing students' learning, although they faced the difficulty of mixedlevel classes.

One idea for helping students engage in TEE is creating an anxiety-free atmosphere in the classroom (Horwitz, 2013). Pappamihiel (2002) indicated that nonnative students were afraid of communicating with experts in the L2. Not only teacher-student communication but also student-student communication through pair and group work should be actively involved. In this study, a teacher successfully adopted pair work between students to lower their anxiety when speaking English, preparing them for English-mediated lessons. Another idea for taking care of students' learning is team teaching. Teachers can provide more support for students in English language classes through team teaching (Honigsfeld \& Dove, 2010). Two veteran female teachers in this study successfully collaborated with each other and helped students catch up with lessons by giving corrective feedback. In addition to developing teachers' English proficiency, adopting student-initiated interactions in an anxiety-free classroom and multiple-teacher collaborations should be considered essential for firmly embedding the TEE policy in JHSs.

\section{Support From Local Governments}

Current in-service training might not successfully contribute to developing confidence for TEE among JHS teachers. Approximately $88 \%$ of the teachers took in-service training related to TESOL methodology. However, the high completion rate did not necessarily lead to each teacher's TEE practice. In fact, more than half of JHS English teachers commented on their anxiety about their command of English, and $44.9 \%$ of the teachers in this study were considered "anxious" about their own English proficiency. To cope with anxiety, teachers requested more practical learning opportunities, such as overseas English training, sabbatical leaves, and online training 
courses to develop their command of English. Of course, individual teachers made efforts to improve their English skills in their busy daily lives, yet nearly $80 \%$ of JHS English teachers did not reach MEXT's required English proficiency level. Thus, local governments in charge of teacher training must make drastic changes to their in-service training and provide new types of practical training to support teachers in the long term. As Butler (2005) and Yamamori (2013) argued, instead of providing methodology courses, more language training courses for teachers should be integrated into the local government training courses. In addition, rather than depending only on individual teachers' efforts, local governments should take a strong leadership approach in providing financial and practical support to teachers, thereby helping to ensure the successful implementation of the TEE policy in JHSs.

\section{Conclusion}

JHS English teachers' reactions to MEXT's new TEE policy in JHSs were explored in this study. Teachers showed relatively positive attitudes to the policy because they understood the benefits of TEE; some actually started before the official implementation of the policy. However, due to their foreign language anxiety and lack of English proficiency, JHS teachers did not have enough confidence to teach English in English. In particular, JHS English teachers' low achievement rate $(20.4 \%)$ on MEXT's English proficiency requirement should be improved before the official implementation of the policy. As Kim (2004) stated, nonnative language teachers must have sufficient target language proficiency to be a language model for students. To carry out communicative lessons in English, JHS teachers should develop their English to prepare themselves for TEE. JHS teachers also struggled to speak English with the spontaneity required to fit the mixed-level students in JHS classrooms. In addition to improving their English proficiency, JHS teachers should learn strategies to cope with such difficulties during inservice training.

The successful implementation of the TEE policy in JHS requires support from local governments. As many researchers (Browne \& Wada, 1998; Kikuchi \& Browne, 2009) have argued, in-service training is an essential factor for the successful implementation of the policy. Regular in-service training should cover topics related to student-centered lessons and team teaching. Local governments also need to recognize the importance of providing teachers with practical English training to develop their command of the language with some financial and practical support. 
This study revealed the reaction of a group of JHS English teachers toward the TEE policy. As with some of the teachers in this study, there are likely to be other teachers who have had a head start and prepared themselves for the TEE implementations. However, given that the majority of JHS teachers appeared to be unprepared for the new policy, it seems likely that many other teachers will require further support. Not only local government in-service training and teachers' self-help efforts, but also locally based professional development opportunities, such as a teacher support group and a training camp sponsored by a local university, should be considered. Carefully listening to teachers' voices at each local level could lead to the successful implementation of the new policy.

Tomohisa Machida is an associate professor in the Graduate School at Akita International University. His research interests include elementary-school English education, foreign language anxiety, and teacher education.

\section{References}

Bannai, A., Ukawa, S., \& Tamakoshi, A. (2015). Long working hours and sleep problems among public junior high school teachers in Japan. Journal of Occupational Health, 57, 457-464. https://doi.org/10.1539/joh.15-0053-oa

Brown, D. H. (2007). Teaching by principles: An interactive approach to language pedagogy (3rd ed.). White Plains, NY: Pearson Education.

Browne, C. M., \& Wada, M. (1998). Current issues in high school English teaching in Japan: An exploratory survey. Language, Culture and Curriculum, 11(1), 97-112.

Butler, Y. G. (2005). 日本の小学校英語を考える:アジアの視点からの検証と提言 [English language education in Japanese elementary schools: Analyses and suggestions based on East Asian perspectives]. Tokyo: Sanseido.

Choi, T.-H. (2015). The impact of the 'Teaching English through English' policy on teachers and teaching in South Korea. Current Issues in Language Planning, 16, 201-220. https://doi.org/10.1080/14664208.2015.970727

Choi, T.-H., \& Leung, C. (2017). Uses of first and foreign languages as learning resources in a foreign language classroom. The Journal of Asia TEFL, 14(4), 587-604. https://dx.doi.org/10.18823/asiatefl.2017.14.4.1.587

Dearden, J. (2015). English as a medium of instruction: A growing global phenomenon. Retrieved from British Council website: https://www.britishcouncil.org/ education/ihe/knowledge-centre/english-language-higher-education/reportenglish-medium-instruction 
Ford, K. (2009). Principles and practices of L1/L2 use in the Japanese university EFL classroom. JALT Journal, 31(1), 63-80. Retrieved from https://jaltpublications.org/jj/articles/272-principles-and-practices-l112-use-japaneseuniversity-efl-classroom

Glasgow, G. P. (2013). The impact of the new national senior high school English curriculum on collaboration between Japanese teachers and native speakers. JALT Journal, 35(2), 191-204. Retrieved from https://jalt-publications.org/jj/ articles/3437-perspectives-impact-new-national-senior-high-school-englishcurriculum-collaboratio

Gorsuch, G. (1998). Yakudoku EFL instruction in two Japanese high school classrooms: An exploratory study. JALT Journal, 20(1), 6-32. Retrieved from https:// jalt-publications.org/jj/articles/2777-yakudoku-efl-instruction-two-japanesehigh-school-classrooms-exploratory-study

Honigsfeld, A., \& Dove, M. G. (2010). Collaboration and co-teaching: Strategies for English learners. https://doi.org/10.4135/9781452219516

Horwitz, E. K. (1996). Even teachers get the blues: Recognizing and alleviating language teachers' feelings of foreign language anxiety. Foreign Language Annals, 29(3), 365-372. https://doi.org/10.1111/j.1944-9720.1996.tb01248.x

Horwitz, E. K. (2013). Becoming a language teacher: A practical guide to second language learning and teaching (2nd ed.). Upper Saddle River, NJ: Pearson.

The Japan Association of National Universities. (2017). 平成 32 年度以降の国立大 学の入学者選拔制度 [National university entrance examination system in 2020 and after]. Retrieved from http://www.janu.jp/news/teigen/20171110-wnewnyushi.html

Kikuchi, K., \& Browne, C. (2009). English education policy for high schools in Japan: Ideals vs. reality. RELC Journal, 42, 172-191.

https://doi.org/10.1177/0033688209105865

Kim, S. (2004). When and how to resolve language issues of nonnative-Englishspeaking teachers-in-preparation in TESOL programs. NNEST Newsletter, 6.

Kim, S.-Y., \& Kim, J.-H. (2004). When the learner becomes a teacher: Foreign language anxiety as an occupational hazard. English Teaching, 59(1), 165-185. Retrieved from http://www.dbpia.co.kr/Journal/ArticleDetail/NODE07096478

Levin, G. S. (2003). Student and instructor beliefs and attitudes about target language use, first language use, and anxiety: Report of a questionnaire study. The Modern Language Journal, 87, 343-364. https://doi.org/10.1111/1540-4781.00194 
Machida, T. (2016). Japanese elementary school teachers and English language anxiety. TESOL Journal, 7, 40-66. https://doi.org/10.1002/tesj.189

Machida, T., \& Walsh, D. J. (2015). Implementing EFL policy reform in elementary schools in Japan: A case study. Current Issues in Language Planning, 16, 221-237. https://doi.org/10.1080/14664208.2015.970728

MacIntyre, P. D. (1999). Language anxiety: A review of the research for language teachers. In D. J. Young (Ed.), Affect in foreign language and second language teaching: A practical guide to creating a low-anxiety classroom atmosphere (pp. 24-45). Boston, MA: McGraw-Hill.

MEXT (2008). 小学校学習指導要領 [Course of study for elementary school education]. Retrieved http://www.mext.go.jp/a_menu/shotou/new-cs/ youryou/1304417.htm

MEXT. (2010). 高等学校学習指導要領解説: 外国語編·英語編 [Course of study for high school English education]. Tokyo, Japan: Kairyudo.

MEXT. (2013). English education reform plan corresponding to globalization. Retrieved from http://www.mext.go.jp/en/news/topics/detail/1372656.htm

MEXT. (2016). 平成 27 年度「英語教育実施状況調査」の結果について [Results of the state of implementation of English education in AY 2015-2016]. Retrieved from https://www.mext.go.jp/a_menu/kokusai/gaikokugo/1369258.htm

MEXT. (2017). 中学校学習指導要領 [Course of study for junior high school education]. Retrieved from http://www.mext.go.jp/a_menu/shotou/newcs/1384661.htm

Meyer, H. (2008). The pedagogical implications of L1 use in the L2 classroom. Maebashi Kyoai Gakuen College Ronsyu, 8, 147-159.

Mousavi, E. S. (2007). Exploring "teacher stress" in non-native and native teachers of EFL. ELTED, 10, 33-41. Retrieved from http://www.elted.net/volume-10.html

Nation, P. (2003). The role of the first language in foreign language learning. The Asian EFL Journal, 5(2), 1-8. Retrieved from https://www.asian-efl-journal. com/1460/main-journals/the-role-of-the-first-language-in-foreign-languagelearning/

Nishino, T. (2011). コミュニカティブ・アプローチに関する日本人高校英語教師の信条と実践 [Japanese high school teachers' beliefs and practices regarding communicative language teaching]. JALT Journal, 33(2), 131-155. Retrieved from https://jaltpublications.org/jj/articles/1208-コミュニカティブ・アプローチに関する日本人高校英 語教師の信条と実践---japanese-high-school-teachers'-beliefs-and-prac 
Nishino, T., \& Watanabe, M. (2008). Communication-oriented policies versus classroom realities in Japan. TESOL Quarterly, 42, 133-138. https://doi.org/10.1002/j.1545-7249.2008.tb00214.x

Pappamihiel, N. E. (2002). English as a second language students and English language anxiety: Issues in the mainstream classroom. Research in the Teaching of English, 36, 327-355.

Pinter, A. (2017). Teaching young language learners (2nd ed.). Oxford, England: Oxford University Press.

Reves, T., \& Medgyes, P. (1994). The non-native English speaking EFL/ESL teacher's self-image: An international survey. System, 22, 353-367.

Sakamoto, M. (2012). Moving toward effective English language teaching in Japan: Issues and challenges. Journal of Multilingual and Multicultural Development, 33, 409-420. Retrieved from https://doi.org/10.1080/01434632.2012.661437

Samimy, K. K., \& Brutt-Griffler, J. (1999). To be a native or nonnative speaker: Perceptions of "nonnative" students in a graduate TESOL program. In G. Braine (Ed.), Nonnative educators in English language teaching (pp. 127-144). Mahwah, NJ: Lawrence Erlbaum.

Storch, N., \& Wigglesworth, G. (2003). Is there a role for the use of the L1 in an L2 setting? TESOL Quarterly, 37, 760-769. https://doi.org/10.2307/3588224

Suzuki, H., \& Roger, P. (2014). Foreign language anxiety in teachers. JALT Journal, 36(2), 175-200. Retrieved from http://jalt-publications.org/jj/articles/4169foreign-language-anxiety-teachers

Tum, D. O. (2012). Feelings of language anxiety amongst non-native student teachers. Procedia-Social and Behavioral Sciences, 47, 2055-2059. https://doi.org/10.1016/j.sbspro.2012.06.948

Weschler, R. (1997). Uses of Japanese (L1) in the English classroom: Introducing the functional-translation method. The Internet TESL Journal, 11(3). Retrieved from http://iteslj.org/Articles/Weschler-UsingL1.html

Yamamori, N. (2013). 外国語活動に求められる教師の教室英語力の枠組みと教員研修プロ グラムの開発:理論と現状をふまえて [Teachers' classroom English ability for foreign language activities and teacher training: Integrating theory and reality].JES Journal, 13, 195-210. https://doi.org/10.20597/jesjournal.13.0_195

Yoshida, K. (2003). Language education policy in Japan: The problem of espoused objectives versus practice. The Modern Language Journal, 87, 290-292. https://doi.org/10.1111/1540-4781.00x165 